\title{
"From phenomenon, throughout the fact, to foundation". Outline of the concept of man and its development according to Edith Stein (1891-1942)
}

\begin{abstract}
Edyta Stein - Sister Teresa Benedicta of the Cross - was fascinated by the "mystery of man". Discovering this mystery led her to experience the "mystery of God". She had a beautiful and difficult road leading through life and scientific transgressions, the path from thanatology to transthanatology, from the existence of a contingent existence to the existence of eternal Being.

According to Edith Stein, the existence of man is unique. Everyone has to discover the fullness of his existence. Here comes Stein's transition from psychological and philosophical considerations (phenomenon-fact) to theological considerations (foundation). By learning about God, man recognizes himself and discovers the ultimate truth of his existence. Whoever does not reach himself will not find God and enter eternal life. Or better: whoever does not find God will not find himself (no matter how much focus he will give on finding himself) and the source of eternal life that awaits him in his own interior ${ }^{1}$.
\end{abstract}

Keywords: Edith Stein, anthropology and pedagogy, life and intellectual transgressions of Edith Stein

\section{Preface}

The intention of the author of this chapter is to present the outline of the concept of man and its development according to Edith Stein (Saint Teresa Benedicta of the Cross), an intellectualist from Wroclaw, from a Jewish family who was baptized, entered a Car-

${ }^{1}$ E. Stein, Finite and Eternal Being, translated by Kurt F. Reinhardt, ICS Publications Institute of Carmelite Studies, Washington D.C. 2002. 
melite order, died a martyrdom death at Auschwitz-Birkenau and became Europe's co-patron, in the context of her life and scientific transgression. For Stein, the question about man was one of the fundamental questions. She sought answers to this question not only in human wisdom but also in the divine one.

\section{Life and scientific transgressions}

In the life of Edith Stein we can talk about life and scientific transgressions. From life's point of view, it is primarily a transition from Judaism through agnosticism to Catholicism; from fascination of the war (working as a nurse) to death in a German concentration camp. From the scientific point of view, this is a transition from psychology to philosophy, from phenomenology to metaphysics, from metaphysics to theology, from thanatology to trans-thanatology.

As the expert of the biography and achievements of Edith Stein - Jerzy Machnacz writes that everything started from dreams, from the desire to know oneself and the experience of another human being in its pure existence. It all started with a conscious, but not fully rational, rejection of the existence of God. And then phenomenology appeared with its phrase "the things themselves" and the people we call witnesses. They spoke to her with their own lives. To the intellectual possibility, to the idea comes its realization, which is existence. Man is able to possess the Truth that is worth living for. He who seeks the truth seeks it with all his mind and with all his heart and all of God's will, whether he is aware of it or not. If one is looking for the meaning of his own existence, one has to look in the depths of his own being, and he will see the ray of God who was, who is and who will be. In the rays of this Light, all kinds of differences, for example national or religious are fading, and while maintaining their own identity, the unity is revealed. Stein "reconciles" being the daughter of her Nation and being the bride of Christ, that is why she is able to lead the dialogue of Saint Thomas with Husserl, and take the road from atheism to a mystical experience. In the cross of Jesus Christ, the values were reevaluated, the order which was at the beginning and which Adam destroyed was restored. God and man are with and for each other again. St. Thomas and Husserl intellectually gave Stein a great deal. Witnesses of the faith, such as Anna and Adolf Reinach, showed her the world so far unknown. But all this "overlaps" with her longing, of which Saint Augustine wrote that the heart of man is restless until he rests in God. Empathy is the gift of experiencing of existence of another person. Mysticism is a gift of experiencing of existence of a personal God. The existence of the second "I" and the existence of God cannot be proven, but one can experience it. No one can understand this, because existence is inconceivable. That is why Saint Teresa Benedicta of the Cross said: Ave crux, spes unica ${ }^{2}$.

2 J. Machnacz, Edyta Stein. Św. Teresa Benedykta od krzyża. Wprowadzenie w życie i twórczość, Wydawnictwo i Drukarnia DTSK „Silesia”, Wrocław 2010, p. 93-94. 
Edith Stein was born in Wroclaw, in a Jewish family on $12^{\text {th }}$ October 1891 . As she wrote:

I was born on the Day of Atonement and my mother always considered it my real birthday [...] My Mother laid great emphasis on the occurrence, and I think, more than anything else, it made her youngest child especially dear to her. [...] In my dreams I always foresaw a brilliant future for myself. I dreamed about happiness and fame for I was convinced that I was destined for something great ${ }^{3}$.

Although she was brought up by her mother in the spirit of Judaic religion, as a young girl she deliberately and voluntarily ceases to pray and does not think about God. However, on the path of her life she meets believers who live according to their faith, after which she becomes open to God. After the death of the husband of Anna Reichenach, whose religious attitude is a great challenge for her, she writes that this was her first meeting with the cross and divine power given to those who carry it. She saw for the first time the Church born of the sufferings of Christ the Saviour in his victory over the goad of death. It was a moment in which her non-believing collapsed, Jewish faith lost its meaning and Christ was victorious, The Christ in the mystery of the Cross ${ }^{4}$. After meeting with Max Scheler, she says:

His influence in those years affected me, as it did many others, far beyond the sphere of philosophy. I do not know in which year Scheler returned to the Catholic Church. [...] he was quite full of Catholic ideas at the time and employed all the brilliance of his spirit and eloquence to plead them. This was my first encounter with hitherto totally unknown world. It did not lead me as yet to the Faith. But it did open for me a region of "phenomena" which I could them no longer bypass blindly. With good reason we were repeatedly enjoined to observe all things without prejudice, to discard all possible "blinders". The barriers of rationalistic prejudices with which I had unwittingly grown up fell, and the world of faith unfolded before me. Persons with whom I associated daily, whom I esteemed and admired, lived in it.

After reading biography of Saint Teresa from Avila in 1921, she decides to convert to Catholicism. On the $1^{\text {st }}$ of January 1922 she is baptized and welcomes the sacrament of Eucharist, and in the same year, on the $2^{\text {nd }}$ of February she welcomes the sacrament of Confirmation. After conversion, on the $14^{\text {th }}$ of October 1933, she is admitted to the Discalced Carmelite monastery in Cologne. On the $15^{\text {th }}$ of April 1934, as a novice she takes on the religious name of Teresa Benedicta of the Cross, and on $21^{\text {st April }} 1938$ Edith takes perpetual vows. On $31^{\text {st }}$ December 1938 the young nun is sent to Carmelite monastery in Echt (the Netherlands). On August the $2^{\text {nd }}$ in 1942 Edith Stein is arrested and taken to a transit camp in Amersfoort and later on to the camp in Westerbork. Her arrival to the

\footnotetext{
${ }^{3}$ Sister Teresa Benedicta of the Cross, Discalced Carmelite, Vol. I: Life in a Jewish family, ICS Publications Washington, D.C. 1989, p.72-77.

${ }^{4}$ R. Posselt, Edith Stein. Einegroße Frau unseres Jahrhunderts, Herder, Freiburg 1963.

${ }^{5}$ E. Stein, Life in a Jewish family: An Autobiography 1891-1916, The Collected Works, Vol. I, ICS Publications 2131 Lincoln Road, N.E. Washington, DC 20002-1199, 1985.
} 
concentration camp in Auschwitz-Birkenau and her death in the gas chamber has been noted on the $9^{\text {th }}$ of August 1942.

Contemplating on life transgressions of Edith Stein - St. Teresa Benedicta of the Cross, two of her statements are worth noticing. On the $26^{\text {th }}$ of March 1939 she writes to her Mother Superior offering herself to the heart of Jesus as a sacrifice for true peace, letting the reign of Antichrist break down, if it is possible without a new world war, and that a new order may arise. Later on she writes that she wants it at that moment, because it is twelve o'clock. And is aware that she is nothing, but Jesus wants it, and He will call many others in those days ${ }^{6}$. Farther she writes:

To suffer and to be happy although suffering, to have one's feet on earth, to walk on the dirty and rough paths of this earth and yet to be enthroned with Christ at the Father's right hand, to laugh and cry with the children of this world and ceasessly sing the praises of God with the choirs of angels - this is the life of the Christian until the morning of eternity breaks forth ${ }^{7}$.

A citizen of the Third Reich, born as the follower of Judaism, Edith Stein - sister Teresa Benedicta of the Cross-consciously and willingly makes breakthroughs in life and gives her life away in an act of sacrifice.

Considering her scientific transgression, few facts are worth noticing. Fascinated with the world of science, in the years 1911-1913 studies on the University of Wroclaw (psychology and philosophy), and then continues in the years 1913-1915 on the University of Göttingen (philosophy, German studies, history). In 1915 she graduates the state exam with a high note. At the same time she serves at the field hospital in Märisch-Weisskirchen. On the 3rd of August 1916 she graduates her doctor of philosophy exam with summa cum laude honor, and in the years 1916-1918 she begins working as an assistant with E. Husserl at Freiburg. The years 1919-1923 are for Edith a futile attempt of submitting her habilitation. Since 1923 till 1931she works as a teacher at school in Speyer. In 1931 she receives the post of a lecturer at the German Catholic Church - affiliated Institute for Scientific Pedagogy in Münster, where she works till 1933.

According to Stein psychology, which she is fascinating with at the beginning of her scientific path, deals with life experiences, mentality. After a short period connected strictly with psychology, Stein turns to philosophy, and most particularly phenomenology, which she studies while being Husserl's assistant. This scientific sphere handles studies of the being, its awareness. Phenomenology is also about the things that can, but do not have to happen. Stein takes an attempt of explaining the subject of "empathy". She works on phenomenological reduction - as a researcher of this field she "has contact with" pure beings, who are ,things" for her. Edith is not interested in the existence of things in the world (natural world is parenthesized), but concentrates on the essence of

${ }^{6}$ Ibidem.

7 The Collected works of Edith Stein; The hidden life; Essays, Meditations, Spiritual texts, edited by Dr. I. Gelber and Michael Linssen, O.C.D., translated by W. Stein, PH.D.; ICS Publications, Institute of Carmelite Studies, Washington D.C. 1992, 2014. 
existence parenthesizing all of the knowledge, tradition and authorities opinions. Stein as the scholar of phenomenology studies the substance (beings) in the area of pure awareness and not psychic experiences. While the time goes by, metaphysics is added to phenomenology. Metaphysics, which is the subject of her studies on Thomas Aquinas' system, deals with the real, existing entity. During this period she tries to bring together phenomenology and the views of Thomas Aquinas'. Stein attempts a dialogue between the two philosophical schools. At the same time, she shows the difference in metaphysical thinking and the one basing on epistemology. Beginning from the fact of (own) entity, she concludes at discovering in her own self the eternal being. Temporal existence, accidentally (the man) points, according to Stein, to the absolute, eternal being. A transition to a theological period starts in this place. In anthropology and metaphysics Stein appeals to God as in realistic metaphysics, the eternal entity justifies the existence of the accidental one. Theology, which became a supplement of her scientific life, deals with God. In theology Stein finds the truth she is looking for - the truth about a man. A man accidental being, with experiences and awareness searches for an ultimate reason of its existence in Immortal Being. Stein is convinced, that faith and reason are instruments (within the limits of their competence) of human cognition.

In the German Institute for Scientific Pedagogy in Münster phenomenological researches of the human being are „compatible" with the catholic teaching about the man. „Theological Anthropology" is the product of her scientific and didactic work. The book aims to show the image of a man in the teaching of catholic faith. In the scientific language of those days, what is done is called dogmatic anthropology. The task appeared during her work related to determining the basics of pedagogy. No one will deny that every teaching about upbringing and educational work is conducted and determined in a decisive manner by the idea of man. However, it is nowhere said that it is an idea already explained and theoretically worked out. If pedagogy claims the right to be a science, one of its important tasks will be to justify its guiding ideas (regarding the human being). Guided by this thought as a lecturer at the German Institute of Pedagogics in Münster, Stein tried to solve the problem in the winter semester of $1932 / 33$ by philosophical means ${ }^{8}$.

\section{Anthropology and pedagogy in Edith Stein's writings}

The Question of a man is one of fundamental questions and a motive for reflection for Stein. The fascination regarding human's existence finds its reflection in the following works: On the Problem of Empathy; Finite and Eternal Being; The Science of the Cross;

${ }^{8}$ Św. Teresa Benedykta od Krzyża, Czym jest czlowiek? Antropologia teologiczna, translated by G. Sowiński, Wydawnictwo Karmelitów Bosych, Kraków 2016, p. 13. 
Construction of a human person. Lecture on philosophical anthropology; What is a human being? Theological Anthropology.

In the work "Construction of a human person" Stein writes that knowing who we are, what we should be, how we can become someone we should be, is the most urgent matter for every human being. Of particular importance is knowledge for the educator or for the representative of education about upbringing. To raise a man means to lead another man so that he becomes someone who he should be. One cannot bring up a child without knowing who a person is and what direction he should be led in and what roads are possible ${ }^{9}$.Stein is convinced that pedagogy builds castles on the sand when it does not have the answer to the question "Who is a man?"10. According to Stein to educate means to lead people to become what they should be ${ }^{11}$.

\section{What does a man mean for Edith Stein - Sister Teresa Benedicta of the Cross?}

The man - a human being is an individual substance of a rationalistic nature, the ultimate subject. A soul is a form of the body, which makes the man a living being, with the corporal-psychic-spiritual character. At the beginning a man is seen by the sensual eyes, it appears as a physical body. Later on the philosophical subject is able to see the existence of a second "I", which Stein calls soul. The man lives in the world of nature and culture. Inside a man, the matter merges with the spirit as we perceive a man as a microcosm in which all stages unite with each other. The Man is a material thing, a man is a living being, a man is a soul-endowed being, a man is a spiritual being ${ }^{12}$.

The man is free because he has a part in spiritual sphere. To be a person - for Stein means to be a free spiritual being. Freedom requires responsibility. She states that when she looks into the eyes of a man - who with his eyes answers her. He allows her to penetrate his interior or defends himself against her. He is the master of his soul: he opens or closes her gates. He is able to get out of himself. When people look at each other, one "I" stands opposite the other "I" - it can be a meeting at the gate of the soul or inside it, then the other "I" is "you". The look of a man speaks. In his gaze, she is observed by the watchful "I" who is the master of himself. It is also called a free, spiritual person. To be a person means to be a free and spiritual being. ${ }^{13}$

9 E. Stein, Budowa osoby ludzkiej. Wykład z antropologii filozoficznej, oprac. B. Beckmann-Zöller, thum. G. Sowiński, Wydawnictwo Karmelitów Bosych, Kraków 2015, p. 282.

${ }^{10}$ E. Stein, Autoportret Edyty Stein w jej twórczości. Wybór pism duchowych, tłum. I.J. Adamska, Flos Carmeli, Poznań 1999, p. 60.

11 Ibidem.

12 E. Stein, Budowa osoby ludzkiej..., op. cit., p. 88.

13 Ibidem, p. 161. 
Stein considers the human through ontological triad: body-soul-spirit. A man belongs to three kingdoms: body, spirit and soul. According to Stein the kingdom of corporeality is the kingdom of "nature" or the kingdom of the earth. Then there is the kingdom of the spirit which is the kingdom of what is heavenly, and the kingdom of the soul, the kingdom of the hidden. The latter - she adds - is the dimension of life not yet revealed, which as such seeks to develop to corporality. But what is heavenly, however, is the realm of development throughout the present and gifted with perfect devotion ${ }^{14}$.

Physical body a man can see through outside observations (it should be noted that it is not the only way of perception). However, such self-observations are something different than a perception of the surrounding world, objects or even the second person. While talking about the human's body, two ways of its folding can be pointed. Not only the characteristics of the body existing only in an outside observation, but also indication of a sensational gaining, bodily seen body. Impressions seem to be remote, as if they are located in a different than one's own space (for example, one can know his foot is hurting, he can see it, but he cannot reach it from the inside). This is, of course, only an illusion, as all the processes experienced by man, that are going on in his own body are real and present just the same as the fact of thinking.

Human body, every carnality states the shape of the man. Through the ability of empathy, one has the possibility of entering the outside world and its creative interference. Edyta Stein assigns him the ability of inner life, talks about the interiority of the body. This interiority can mean a closed monad, or psyche, from which soul should be distinguished as something even more internal of all the interiority. Feeling the states of the body for spirit and soul are the most outside outskirts of internal life. The more a man delves into his interior the more he turns away from his body and breaks away from it. Life between two poles: addition to the body and complete freedom from its boundaries. As Stein writes the less the soul gives itself to the body, the more it takes its form, because the body can change with the soul, can shine through its light and radiate $\mathrm{it}^{15}$.

Edith Stein's thoughts around souls are inseparably connected with the existence of a human being, with a sentient, alive individual. The soul is a kind of "inhabitant" of the body, gives it vividness, gives it the ability to live. Stein claims that the soul is the carrier of our experiences. As she states in peoples' experiences a man is presented with something lying at his base, which reveals itself and its permanent properties, as its carrier is identical: this is a substantial soul ${ }^{16}$.

The soul is not only a form of body in a man, but also a center of existence. You can say that she lives in herself and that is where the personal self is found. The human soul, as the spirit and image of the Spirit of God, is to affirm the entire created world, knowing

\footnotetext{
14 E. Stein, On the Problem of Empathy; the Collected Works of Edith Stein; translated by W. Stein, ICS Publications 1989-135.

15 E. Stein, Twierdza duchowa, tłum. J.I. Adamska OCD, Zysk i S-ka Wydawnictwo, Poznań 1998, p. 76.

${ }^{16}$ E. Stein, On the Problem of Empathy..., op. cit.
} 
and loving it, to see in it its calling and act accordingly. Thanks to the soul, the human person can go out to the outside (matter susceptible to shaping), but it is also the place where the being opens towards the interior. The soul mediates between the spirit and the body: spirituality and sensuality converge in it, mutually interweaving. Depending on whether the soul is directed towards corporality or spirit, we are talking about a spiritual soul, or a sensual soul ${ }^{17}$.

According to Stein, a man crosses the boarders of nature and takes part in the spiritual world:

So far we have considered the individual "I" as a part of nature, the living body as a physical body among others, the soul as founded on it, effects suffered and done and aligned in the casual order, all that is psychic as natural occurrence, consciousness as reality. [...] In the constitution of the psycho-physical individual something already gleamed through in a number of places that goes beyond these frames. Consciousness appeared not only as a casually conditioned occurrence, but also as object-constituting at that time. Thus it stepped out of the order of nature and faced it. Consciousness as a correlate of the object world is not nature but spirit ${ }^{18}$.

The spiritual sphere is an internal life space. In this space, awareness and understanding of the surrounding world develops, not only as an external reality, but also as a symbolic product, a product of human culture, a product of the spirit. Edith Stein emphasizes clearly that the issue of spirit or spiritual space, which this spirit permeates, one cannot approach as phenomena or objects of nature. The world of good, values or creativity as an object of the spirit sphere does not affect in any way the natural world, in the strictly material sense. Thus, the spiritual space is the inner depth of the person who only develops himself, in the material body there is the space that enables man to experience states distinguished only for him, thus constituting the essence of the person ${ }^{19}$.

The word "ghost" has a double meaning and should be understood as a spiritual person and as a spiritual sphere. According to this distinction, the spiritual person has his personal center in spirit, but on the other hand, he can develop in the spiritual sphere, like a saint or directly God. In full development, we can talk about spiritual realization. The spirit which is meaning and life is heading towards the deepest sense of creation which is Christ and in the full realization the sense of individual life is filled with the other Divine Person ${ }^{20}$.

The ontological triad of body-soul-ghost is enriched with functional triads related to the actions of the authorities. The first is: spirit, love and cognition. The second triad consists of memory, reason and will. Edith Stein cites another anthropological triad, derived from psychological research: thinking, feeling and wanting.

${ }^{17}$ E. Stein, Finite and Eternal Being, translated by K.F. Reinhardt, ICS Publications Institute of Carmelite Studies, Washington D.C. 2002.

18 E. Stein, On the Problem of Empathy..., op. cit.

${ }^{19}$ Cfr. http://www.filozofia.org.pl/ff/ff5/teksty/fenomenologiczna_mysl_antropologiczna_e_stein.pdf.

${ }^{20}$ Cfr. E. Stein, Twierdza duchowa..., op. cit., p. 43. 
It should be noted that despite such separation and attempts to explain the "elements" that make up human existence, in Edith Stein's anthropology "elements" are closely related to each other, complementing each other and forming a whole. The body does not exist without the soul and spirit, the spirit without body and soul, and the soul without spirit and body. You can look at a human being as a thing and as a person. You can refer to a human being as something and as someone. Objectification will always lead to exploitation of a man by man.

In her anthropological reflections, Edith Stein distinguishes between the person and the "I". The "I" becomes the subject of current experiences, it is accessible and vivid in these experiences. By "I" we mean being, whose existence is life (namely life not in the sense of matter, but as the development of the "I" in its existence) and which in this existence realizes itself (in the lower form of vague sense sensation or in a higher form of awakened consciousness). "I" is not synonymous with soul or body. "I" dwells in the flesh and in his soul, present in every point where it feels something present and alive, even though it has its right seat taken at a specific point in the living body and in the specific place of the soul. Because the "I" belongs to its body and its soul, the term "I" also extends to the whole person. Not all physical life is the life of "I". The watchful and conscious life of the "I" is the way to the soul and its hidden life, just like the body and its hidden life that leads a sensual life. It is a path because it is a manifestation of what is happening in the soul and the discharge of its essence. Everything that "I" experience comes from the soul; it is her meeting with something that impresses on her. This point of attachment or exit in the soul can take place more on the surface, but already in its depth. The said "where from" and this order of layers of the soul, reveals itself through experiencing which of them grows, and because they are open and come to their currently living existence ${ }^{21}$. Every "I" is oneoff, in some way closed in itself, present to itself. It has something that it does not share with any other being, i.e. it has something unspeakable, something familiar, so it is one of a kind. This separates it as an inalienable property of existence ${ }^{22}$.

According to Stein, the proper area of life of the human person is the world of the spirit. It is a world of values. Entering the world of our values is an insight into our personality. As following this schema we can say that in the act of empathy, my I "reveals" myself, "gives" myself to the other self. And the second "I" - another entity "shows" its existence to me, "shows" to me what values it lives on. We experience someone in the first place. The act of empathy is an act of physical-corporal-psycho-spiritual ME, the act of a human person who "comes out" from a human person, is directed towards the person and what the person "achieves".

Stein emphasizes the distinction between a person and "I". As she claims not every "I" has to be personal. However, each person must be sure of "I" to realize one's own existence, because it results from rationality. The conscious and free "I" can be under-

\footnotetext{
21 E. Stein, Finite and Eternal Being, op. cit.

22 Ibidem.
} 
stood as a free person, because one is the "master of his own deeds", because one determines his life. Free acts are the first domain of the reign of a person. However, because a person through his actions exerts a shaping influence on the body and soul, his entire "human nature" belongs to the scope of its power; it also has a certain scope of power in the world around it, and it can consider this range as "its own", because it can influence the surrounding world with its psychophysical action. What a person does in a free and conscious way is the life of the "I", it draws out from the depths, sometimes larger, and sometimes smaller, for example, the decision to go for a walk comes from a layer much more superficial than the decision to create a life. This depth is the depth of the soul, which becomes alive and glows when it was hidden before. However, despite this brightening, it does not cease to be full of secrets. What man can "as a free person" experiences it when he acts on it, or even in a certain prejudice, when it becomes a requirement before $\operatorname{him}^{23}$.

According to Stein a man is free and responsible for what he will become. Following Stein we can ask, what does it mean that man is responsible for himself. Well, it means that he depends on what he is, and that he is required to make himself a definite essence as the man can and should form himself $\mathrm{f}^{24}$.Stein states that freedom is one of the attributes guaranteed by the constitution. However, what does freedom mean? It means "I can". A man is not defenseless, he relies on the stimulus and reaction: he can resist, he can stop something that is growing in him. From "I can" results "I should". A free "me" who can make a decision that he will do something or give up, that he will do this or that. Because he can hear a request and follow it, he is able to set goals and implement them in action. "I can" and "should", "I want" and "I act" are connected with each other internally ${ }^{25}$.

In this way, we are entering the issue of shaping a human being, the development of a human person. All living beings - and so does a man - are real, but not "finished". More important than the structure of being is the fact that man becomes more than he is. As Edith Stein describes it, man realizes himself, he appears in the kingdom of becoming $^{26}$. Man, therefore, appears to us as a being who must "come to himself", to "grow up" to himself, reach his "fullness". This process obtains its finish when man unites himself with God. Obtaining such a condition is his goal. The development which is to lead to it is both the work of the essential form in which the goal force is directed, as well as in the pure form, from which the "direction and impulse" comes from, as a "summoning" that the given creature becomes what it should be.

According to Edith Stein, pedagogy should be aimed at the overall formation of a man in such a way as to enable him to achieve the fullness of existence. The fullness of existence does not consist of self-realization (understood in the egoistic sense) or in

\footnotetext{
23 Ibidem.

${ }^{24}$ E. Stein, Budowa osoby ludzkiej...., op. cit., p. 161.

25 Ibidem, p. 162-163.

${ }^{26}$ E. Stein, Finite and Eternal Being, op. cit.
} 
constructing oneself (understood in the constructivist sense), but in approaching oneself in order to achieve the ultimate mystery that is every human being. Education takes place in tension between the body and the spirit of man, between earth and sky, with the help of natural and supernatural forces.

Stein, like Augustine, finds the thought of directing man to God. In the interior as well as on the outside world, man finds the clues which return him towards something that exists above him and above all, to something from which he himself and from what everything is dependent ${ }^{27}$. Elsewhere, Stein claims that a human being, as any finite being, refers to God and one would not be able to understand being without reference to God's being: neither in the sense that it exists, or in that it is what it is. ${ }^{28}$

Edith Stein thinks that inner experience gives us the experience of God living in one's soul. Man opens himself in the same direction to which he was attracted by a special grace. One can find out about living God in the soul in three ways:

- due to internal experience,

- survival ability,

- experience of obligation (internal demand) ${ }^{29}$.

Therefore, pedagogy must be open to theology and draw from God's revelation. Thus by ceasing to derive pedagogy from Revelation, it risks to skip the most important knowledge that can be obtained, when it comes to man, about his goal and the path to his goal; therefore, by the very principle, pedagogy will not be able to sufficiently determine its subject (that is, educating a man). Only when it is established, admittedly revealed about the subject of man and his upbringing, what is available for natural cognition and what is not can be checked. In the case of what is naturally knowable, one can look for natural justification; when it is found, supernatural justification ceases to be indispensable (within pedagogy). What excludes natural justification should be integrated into the pedagogy. Thanks to this, pedagogy, without becoming theology, will enter into an essential and irremovable relationship with $\mathrm{it}^{30}$.

The pupil and the educator deal with unique existence. Both are to discover the fullness of their existence and shape themselves. Since the full truth of his existence man discovers in the existence of God, pedagogy cannot give up the truth of the existence of God. Education for Stein is a joint work of God and man. It is God who is the proper Educator. The human educator is an example for a foster child. The work of the educator over education is their cooperation on the path to God.

Man has the fullness of existence in the cross of Jesus Christ. In the book "Science of the Cross" Stein looks at man in the perspective of the Creator. Man is a being called to co-exist with God.

\footnotetext{
27 E. Stein, Budowa osoby ludzkiej..., op. cit., p. 90.

28 Ibidem., p. 279.

29 E. Stein, Finite and Eternal Being, op. cit.

30 E. Stein, Budowa osoby ludzkiej..., op. cit., p. 283-284.
} 
Life here has a double meaning: the beatific vision of God to which we can attain only through natural death; and the perfect spiritual life in the union of love with God, which one arrives at after total mortification of all the vices and lust. What the soul calls death here is "all that goes to make up the old self...the entire engagement of the memory, the intellect and the will in the things of the world... and the desire and inclinations that are directed to creatures". All of this constitutes the old life, which cannotes death of the new, spiritual life.

All this is a manifestation of old life and is the death of spiritual life. In the new life of union, all lusts and authorities of the soul, all its tendencies and activities are divinized. The soul lives the life of God. Thus her death has been changed to life, her animal life to spiritual life. The Reason is transformed into divine reason; will, memory and natural desires have been divinized. The substance (sustancia) of the soul is not divine substance, since it cannot undergo the conversion in God substancially (sustancialmente), but through union with God and through being absorbed in him, she is God by participation $^{31}$. The ultimate measure of man is therefore to elevate his existence. In unity, cognition, love, service, the three deepest spheres of human activity, unite in seeing God in his compassion. Man, conforming to God, finding himself in God, at the same time finds the fullness of his humanity.

\section{Bibliography}

Machnacz J., Edyta Stein. Św. Teresa Benedykta od krzyża. Wprowadzenie w życie i twórczość, Wydawnictwo i Drukarnia DTSK „Silesia”, Wrocław 2010.

Posselt T.R., Edith Stein. Einegroße Frau unseresJahrhunderts, Herder, Freiburg 1963.

Sister Teresa Benedicta of the Cross, Discalced Carmelite, Vol. I: Life in a Jewish family, ICS Publications Washington, D.C. 1989, p.72-77.

Stein E., Autoportret Edyty Stein w jej twórczości. Wybór pism duchowych, tłum. I.J. Adamska, FlosCarmeli, Poznań 1999.

Stein E., Budowa osoby ludzkiej. Wykład z antropologii filozoficznej, oprac. B. Beckmann-Zöller, tłum. G. Sowiński, Wydawnictwo Karmelitów Bosych, Kraków 2015.

Stein E., Finite and Eternal Being, translated by K.F. Reinhardt, ICS Publications Institute of Carmelite Studies, Washington D.C. 2002.

Stein E., On the Problem of Empathy; the Collected Works of Edith Stein, translated by W. Stein, ICS Publications 1989-135.

Stein E., On the Science of the Cross, translated by J. Koeppel O.C.D.

Stein E., Twierdza duchowa, thum. J.I. Adamska OCD, Zysk i S-ka Wydawnictwo, Poznań 1998.

Stein E., Was ist der Mensch? Einetheologische Anthropologie, Herder, Freiburg 1994.

Św. Teresa Benedykta od Krzyża, Czym jest człowiek? Antropologia teologiczna, tłum. G. Sowiński, Wydawnictwo Karmelitów Bosych, Kraków 2016.

The Collected works of Edith Stein; The hidden life; Essays, Meditations, Spiritual texts, edited by Dr. I. Gelber and Michael Linssen, O.C.D., translated by W. Stein, PH.D., ICS Publications; Institute of Carmelite Studies, Washington D.C, 1992, 2014.

\footnotetext{
31 E. Stein, On the Science of the Cross, translated by J. Koeppel O.C.D.
} 